\title{
English Language Teachers' Experiences on School Inspection at Primary School level in the Shiselweni region of the Kingdom of Eswatini
}

\author{
Nkosingiphile Ngcamphalala*, Zodwa Gcinaphi Nxumalo, Sithulisiwe Bhebhe \\ Faculty of Education: University of Eswatini, Kingdom of Eswatini Kwaluseni, Eswatini
}

DOI: 10.36348/jaep.2019.v03i09.003 | Received: 03.09.2019| Accepted: 20.09.2019| Published: 30.09 .2019

*Corresponding author: Sithulisiwe Bhebhe

\section{Abstract}

This paper sought to establish primary school English Language teachers' experiences that they encounter during schools' inspection. Underpinned by the MacBeath Cube theory of Evaluation, a qualitative research approach was adopted where a case study research design was utilized with a purposively selected sample of fourteen (14) primary school English language teachers who had been picked from two schools that had been identified as underperforming. Data were analysed using thematic content analysis. The paper was based on the following research questions: What are the challenges encountered by English language teachers during schools' inspection? How can the challenges encountered by English Language teachers during schools' inspection be minimized? The findings of the study revealed that some of the challenges encountered by English language teachers during schools' inspection were that, inspectors disrupted teaching and learning as they came unannounced; inspectors harassed, rudely reprimanded and disrespected the English language teachers; inspectors instilled fear on the teachers because they harshly criticized them and they also confused the teachers as they gave different insights on how best to teach English Language; inspectors threatened teachers with their jobs. The findings further revealed that all these challenges could be minimized if inspectors could respect teachers and provide constructive criticism. Based on the findings, the study recommends that inspectors should annually plan and announce dates for their visits and that the inspectors should follow the inspection guidelines when they visit schools. The study further recommends that the Ministry of Education should establish a policy which protects teachers from being harassed by the inspectors.

Keywords: School inspection, accountability, quality control, effective school, academic performance, school inspectors, challenges.

Copyright @ 2019: This is an open-access article distributed under the terms of the Creative Commons Attribution license which permits unrestricted use, distribution, and reproduction in any medium for non-commercial use (NonCommercial, or CC-BY-NC) provided the original author and sources are credited.

\section{INTRODUCTION}

The issue of providing and ensuring quality education is the core mandate for many countries in Europe and in Africa, including the Kingdom of Eswatini. According to the United Nations Emergency Children's Fund, UNICEF [1], quality education includes among other things producing learners who are ready to participate and learn, environments that are healthy, safe, protective, and gender sensitive, that provide adequate resources and facilities. It also includes providing learners with content that is reflected in relevant curricula and materials for the acquisition of basic skills, and all this may be accomplished through schools' inspection [1].

Schools inspection is a quality control mechanism, which exists in almost all countries. It is also considered to be a means through which education providers can be held accountable for the standards of educational services and outcomes. The purpose of inspection is both to ensure accountability and to enhance performance of schools according to the education policy goals and purposes [2]. Schools' inspection is therefore a practice that should be done in schools since it is one way of ensuring the provision of quality education in schools. The Ministry of Education's core mandate in the Kingdom of Eswatini is the provision and attainment of quality education for all school going pupils and this mandate can be accomplished through schools' inspection [3].

\section{Background of the study}

Schools' inspection is done for varied purposes in different countries. In Europe, schools' inspection is done to monitor and improve the quality of schools and it is also a means through which the Ministry of Education justifies itself to the public and to policy makers so that even if a school does not produce 
the desired results school inspectors can provide documentation to the effect that they did their part [46]. In many countries, schools that underachieve attract the inspectors' visitation [7]. Schools that fall under the worst performing category are inspected to identify the problems that the schools are encountering with the hope that their shortcomings in failing to provide quality education can be minimized [7].

According to Wilson [2] school inspection has attracted considerable interest not just in Europe but in other countries as well around the world. In North America, inspection is seen as a possible alternative to school evaluation. Wilson [2] declares that for over a 150- year history, inspection has evolved a methodology that portrays and judges the quality of what actually happens in schools. For Wilson [2] in North America schools' inspection has managed to keep the issues of quality, assessment, and support of schools directly tied to schools and has provided consistent information both to policy-makers and school practitioners. However, Hargreeaves [8] bemoans the lack of adequate research demonstrating the effectiveness of inspection as a route to school improvement, hence this research.

In the United States of America Wilcox and Gray [2] posit that failing schools are the ones that are inspected. This is done on the premise that the teachers will get assistance after their weaknesses and strengths have been identified. From the inspection's feedback it is hoped that schools will yield academic improvement. However, Brimblecombe, Ormston and Shaw [9] lament that inspection results to stressful experiences on the part of the observed teachers. Much of the teachers' anxiety is associated with being observed while teaching. The worry is that it is never known how long a teacher will be inspected and it is never known what the inspectors are looking for, so teachers are constantly on the edge. The anxiety rises because it is also not known how many inspectors a teacher can expect in his or her class. The theorists further argue that the anxiety intensifies since the inspector sits, looking at everything that is happening in the classroom in the corner like a tutor on teaching practice [9].

In Netherlands, like it is the case with many countries, schools that are underperforming are inspected regularly since the belief is that teachers and the schools will attain academic excellence after receiving constructive individual feedback from the inspectors on how improvements can be made [7]. For the Ministry of Education in Netherlands, a primary school is weak if the school has shortcomings in the quality of education that it provides which is seen in insufficient student achievement results and an inadequate teaching and learning process [7]. The theorists add that weak schools in Netherlands are constantly observed by the inspectorate office and this is done for such schools to be effective [7].
According to Rothman [10] in the Netherlands, the Education inspectorate assesses all schools receiving public funds both independent and public on a regular basis. These inspections are designed to make sure that the schools' funds are being spent appropriately, the curriculum is in place for the required subjects, and the attainment targets are being met. Inspectorate staff members, who are mostly former educators, inspect all schools once every four years, but the Inspectorate intensifies inspections of the small percent of schools deemed to be low-performing. The inspectorate reports are public, and in addition to school reports they publish a national report each year summarizing their findings on schools across the country.

In the United Kingdom, schools that require special measures are schools which are failing to give pupils an acceptable standard of education and where the persons responsible for leading, managing, or governing these schools are failing to demonstrate the capacity to secure the necessary improvement [11]. In the United Kingdom it is compulsory or mandatory that underperforming schools are inspected in order for the teachers to be equipped with the necessary ammunition essential for improving the teaching and learning process [12].

McAleavy and Elwick [13] report that improvement has not solely been seen in the examination results obtained by pupils in London schools. Inspection data from the national schools' inspection body (OFSTED) suggested significant changes in the overall effectiveness of schools and the quality of teaching in London between 2000 and 2013. Based upon inspection judgments (ratings of good or better), schools in London have gone from performing below the national average to exceeding it. Although this swing is evident in primary schools (for students aged 5-11) it is even more marked in secondary phase schools (for students aged 11-18), where there has been a swing of 17 percentage points in overall effectiveness and 21 percentage points in the quality of teaching.

According to Jones and Tymms [14] in England and Wales, the inspection of schools carried out under the auspices of the Office for Standard in Education (OFSTED) is now an everyday fact of life. This is done to assist underperforming schools to better perform. The work of OFSTED and the process of school inspection, continues to generate much discussion and controversy. Hardly a week goes by without the popular or educational press commenting on some aspects of The Office of Standard's activity. The comments are that inspectors are often too harsh and intimidate the teachers hence teaching and learning suffers. School inspection also results in non-conducive teaching and learning environments. For Close [15] in England, schools value inspectors who behave 
professionally, and who are in tune with the schools' aims, purposes and values, and understand its contexts. Schools are critical of inspectors who behave unprofessionally as this overshadows the validity of the inspection and the extent to which it influences the teaching and learning practice. In this regard it is vital that school inspectors behave/conduct themselves professionally so that their mandate can be a success [15].

In South Korea schools are evaluated annually by inspectors and overseen by the metropolitan/provincial education offices [10]. They complete school inspections based on a Ministry of Education evaluation plan, which sets directions and standards. Although local governments can select inspectors, most rely on experienced teachers and school leaders. School evaluations review teaching and learning practices, curriculum, and student needs. The Ministry of Education has even added school-based performance awards in which top-performing schools receive bonuses. School reviews are not used punitively; rather, struggling schools are given advice and guidance on how to improve. Low-performing schools are monitored regularly to see if the improvement plans result in higher levels of student learning. The results of school evaluations are reported publicly.

Rothman [16] points out that in Taiwan, the Ministry of Education inspects upper secondary schools and intervenes in those that are low-performing. The low-performing designation is based on a Ministry evaluation of school management and school leadership practices. An on-site counseling group made up of university professors and experienced principal's coaches the teachers of low-performing schools for one year. A follow-up evaluation is conducted the following year to make sure performance has improved. Local governments oversee elementary and junior secondary schools. Schools that are rated as underperforming in any aspect of the evaluations must make plans to improve themselves with the assistance of school inspectors from the local Bureau of Education. If a school does not improve, there are additional follow-up inspections focused on those areas of weakness.

According to Education and Training Inspectorate (ETI) [5], schools in Northern Ireland are not required to conduct self-evaluation; however school development planning involves an element of this. Schools must use performance and other data to evaluate the school's strategies for a range of areas, including teaching and learning and staff development. ETI uses this to provide evidence of good leadership and in particular the actions taken to drive improvement. A team of inspectors visit the school, ranging from two inspectors for a small primary school to up to eight for a large post-primary undergoing standard inspection. Evidence is used to inform judgments, and there is a particular emphasis on classroom observation. Evidence also includes, interactions with pupils during lessons (to determine what pupils understand and the extent to which they are supported), quality of work in pupils' books (to benchmark the work observed with previous learning experiences), conversations with teachers and managers, documentation produced by the school, responses to an ETI questionnaire by parents, teachers and support staff (used to support identification of lines of enquiry), and a discussion with senior management on the school's performance data. ETI [5] adds that inspection teams take part in a moderation conference immediately after the school's inspection. This aims to ensure that the gathered evidence is challenged and moderated. Managing Inspectors (MIs) join a sample of moderation meetings for quality assurance purposes and all reports are reviewed by MIs prior to issue.

According to House of Common Education Committee [17] school inspections were abolished in Finland in the early 1990s, and instead the education system relies on the effectiveness of teachers and other personnel. Finland places significant trust in classroom teachers and principals, and they are given considerable autonomy. This means that there is no call for formal regulations through inspection. Focus is on selfevaluation within schools and national evaluations of learning outcomes through annual tests undertaken by samples of schools. House of Commons Education Committee [17] adds that the results of national evaluations are not used to rank schools; rather to monitor progress at a national level. Requirements around self-evaluation vary by local authority. Research suggests that while criteria for self-evaluation have been defined, their use in practice is questionable.

According to Rafaeli [18] for too many schools in Sub-Saharan Africa, inspections call to mind a burdensome box-ticking exercise. But, done well, school inspection is an art which has the potential to transform teaching and learning for the better. One of the biggest challenges that the education world is facing is that improving access to education does not necessarily lead to improved learning outcomes. To illustrate this less than 50 per cent of grade 6 students in Southern and East Africa are able to read beyond basic word identification. Rafaeli [18] adds that there is an urgent need for education systems to understand whether teaching and learning is taking place and why it is succeeding or failing in improving learning outcomes. One of the best ways to do so is inspection systems, as they have become a strategic priority for education ministries in low-income countries.

The importance of school inspection is also noted in African countries. According to Matthew [19] in Nigeria, underperforming schools attract inspection. Matthew [19] further argues that inspection offers a 
fresh and independent view and, hopefully, helpful recommendations for development in such schools. According to the Education Law of 1954 in Nigeria, an inspector may be required to perform all or any of the following functions; provide the commissioner with knowledge of all institutions and their potentials and with expect views on educational matters, assess and report on the efficiency of an institution by inspection, offer all possible assistance to teachers in maintaining educational progress, supervise, assess and report on the arrangements for the training of teachers, maintain a thorough knowledge of educational development through study, research and travel, and advance educational progress by the compilation of pamphlets and handbooks on general or particular aspects of education, establish and maintain relations with local and national, industrial and commercial enterprises and professional bodies, so as to enable the Commissioner to secure training schemes, suitable training, in type and volume to their needs and organizing and conducting in service workshops.

In Uganda, school inspectors visit schools once in an academic year for purposes of ensuring quality learning delivery. However, this has been found not to be adequate [20]. In addition, inspection has led to poor relations between teachers and inspectors as teachers feel that the inspectors are intruding in their territory; hence school results were affected [20]. Wardworth et al. [21] point out that in Zimbabwe, school inspectors are termed as quality control personnel for the reason that they are the regulatory processor which measures the actual quality performance, compares it with standards and acts on differences. Thus, in this country school inspectors enjoy the monopoly of detecting quality and defects in education [21].

In South Africa something similar with regards to school inspection is done. According to the Public Service Commission (PSC) Act, [22] every public institution in South Africa is subject to be inspected upon the demand of the commission for ensuring the performance of function. The role of an inspector is to monitor the standards, quality, efficiency and ethos of the schools and to inform both the government and the general public on these matters, in this regard inspection demonstrates the accountability of schools [23]. The intention of inspection is to do more than just regulate; but it is also to promote good relations through improvement of the inspection arrangements and, above all, to provide a system and condition which facilitates school improvement.

Despite the good work that schools' inspection seems to be doing in South Africa, teachers' unions in South Africa show a strong opposition against the inspection system. In their view inspection is more about criticising and harassing teachers by external interference. The unions feel inspection is policing them. It is for this reason that The Department of Education spokesperson of the KwaZulu-Natal province, Muzi Mahlambi, stated in this regard that teachers do not need to be policed [23].

Davies and Ellison [24] further explain that there are a number of challenges for school inspection in South Africa. Some of these include the threat of school closure by inspectors, the need for additional resources, and the need for better relationships with education stakeholders to come up with a solution to combat stay away actions, strikes, mass actions, goslows and violence that repeatedly disrupt education in South Africa. Inspectors in South Africa do monitor progress and improve the quality of schools although the country has not fully recovered from its apartheid era challenges hence there is still a lot of violence in the schools.

According to the Ministry of Education and Training [3] in the Kingdom of Eswatini, there are thirty two regional Primary school Inspectors responsible for inspection and monitoring of schools. Their mandate is to ensure that quality teaching and learning is achieved. Primary school Inspectors are generalists- that is, they do not specialize during inspection. They inspect all the school components including the school administrator's record books. Hamid, Bisschoff and Botha [25], report that in Eswatini the Ministry of Education is tasked with the supervision and monitoring of schools. Chief Inspectors as well as Regional Education Officers (REO's) serve this function. The REO represents the Ministry of Education at a regional level. REO's at a Regional Education board level are responsible for education issues such as pre-approval of new public and private schools. They also work in tandem with teacher training colleges to ensure planning for teacher in-service training. Hamid et al. [25] add that the government has increased the number of regional inspectorate by 13 and The Ministry is awaiting 9 more new inspectors to be appointed by the appointing Commission.

In the Shiselweni region there is a Teachers' Capacity Building programme funded by World Vision to ensure that there is quality education in five language skills, namely; letter knowledge, phonemic awareness, reading comprehension, reading fluency and vocabulary in all the subjects taught in the primary schools, but more emphasis is put in English since it is a subject that determines a learner's progression from one grade level to the next. Teachers are workshoped by the inspectors from the Ministry of Education frequently and observed as often as possible. However, some of these schools are still underperforming more especially in English. This is revealed by the Examination of Swaziland (ECOS) Report for 2016-2017 academic year which claims that despite the Ministry of Education's effort of increasing the number of inspectors, some schools are still underperforming. The whole country still 
experiences such [3]. It was against this background that the researchers embarked on this study.

Inspectors who are experienced teachers, visit schools and directly observe classes and make judgments about the quality of the teaching and learning based on the evidence they collect at school [2].Wilson [2] further says through a team moderation process the judgments of individual inspectors are discussed and a corporate judgment is agreed upon by the inspection team. The results are reported back both to school headteachers and teachers and policy-makers. After inspection has been conducted in schools and anomalies that the teachers are doing have been identified, inspectors conduct workshops to address these anomalies and teachers benefit. Another thing that is done in the workshops is that teachers are equipped with the latest strategies which they can use to improve their instruction in the different subjects. In the same workshops teachers are made aware of any innovations in the curriculum as well as educated or reminded on how each subject should be taught to enhance quality school performance. For Buie [8] inspection is a twoway process where inspectors are viewed more as professional coaches. This view of schools' inspection is seen as a developmental strategy that is aimed at improving the teachers' teaching skills rather than an activity that is meant to frustrate them.

School inspection is mainly for monitoring purposes as inspectors check teaching and learning impact, check school enrolments, payments and usage of funds as well as support schools through school administration [3]. Also like in England and the U.S and the other countries, in the kingdom of Eswatini schools that are underperforming academically are those that are inspected regularly. The background on schools' inspection reveals that inspection is a process/ practice that is undertaken to ensure quality teaching and learning and also that schools are administered and managed appropriately. It has also shown that schools that are regularly inspected are those that underperform. The background also revealed some kind of negative attitude from some unions and teachers who instead of viewing inspection as a practice that is aimed at helping them teach better they view it as that which is aimed at harassing and policing them. Another thing that was unveiled in the background is that in the Kingdom of Eswatini English language is important since it is the official language as well as a passing subject in SPC and all the other external examinations. Even for entry into tertiary institutions learners are required to get good grades in English language.

\section{Statement of the Problem}

The problem in the study is that despite that schools' inspection is carried out in schools, especially for English language, learners still fail the subject yet schools' inspection is done with the belief that after getting feedback from the inspectors the schools' results will improve. Schools' results for the Shiselweni region of the Kingdom of Eswatini have not improved despite that the schools are frequently inspected. For instance in 2017 only 193 primary schools received $100 \%$ pass rate out of 594 primary schools in the Shiselweni region. This means only $32 \%$ of the primary schools attained $100 \%$ pass rate and $68 \%$ did not. The schools inability to attain $100 \%$ pass rate was as a result of learners having failed English language [3]. Ideally the learners should all pass since inspection is administered frequently, more especially with underperforming schools.

\section{Research Questions}

The study was based on the following research questions:

- What challenges do primary school English Language teachers encounter during schools' inspection?

- How can the challenges encountered by primary school English Language teachers during schools' inspection be minimised?

\section{Theoretical Framework}

The study was framed in MacBeath's cube model of evaluation [26] which states that there are two important forms of evaluation that should be carried out in the schools. These are self-evaluation/ internal evaluation which is done by teachers and headteachers and external evaluation which is done by inspectors. According to this model "a successful and lasting marriage" between internal or self-evaluation and external evaluation can have a positive impact on school improvement [26]. What this means is that there is need for external evaluation after self/internal evaluation has been done to ensure that learning will improve. According to the model, "any tension between self-evaluation and external inspection can result in undesirable side effects and imbalances such as negative perceptions of evaluation systems and strategies, particularly among teachers [27]". This model assumes that the teachers' selfevaluation/internal evaluation should be complemented by external evaluation. During internal evaluation teachers evaluate their own teaching through the learners' performances in tests, homework, classwork, to name a few. If the teachers discover that the majority of the learners are failing the work given to them, they may decide to reteach using a different strategy or integrate the teaching methods in order to ensure that their teaching is effective [26]. Again headteachers check the test books to see if the tests are up to the required standard. For this model after internal evaluation has been done there is need for external evaluation in the form of inspectors who will visit the schools in order to observe whether teaching and learning is done accordingly. The theory maintains that both internal and external evaluation work well together to enhance school improvement as well as learners' academic performance. The cube model theory also 
entails that there must be collaboration between all the school's stakeholders and this is termed as the support. The cube model is for the idea that training individuals result in the development of competency. It ensures that school inspection, self- evaluation, internal evaluation (classroom visitation by principals to observe teaching practice), external evaluation (examinations and inspection) assist the school administrators to ensure they attain academic excellence [26].
This model is relevant to the study on the experiences of English language teachers on the challenges that they encounter during schools' inspection in that the challenges would reflect an imbalance and lack of harmony between the two most important aspects of evaluation, that is, self/internal evaluation and external evaluation which could lead to schools not improving and not being able to provide education that is of good quality which could enhance the performance of the learners.

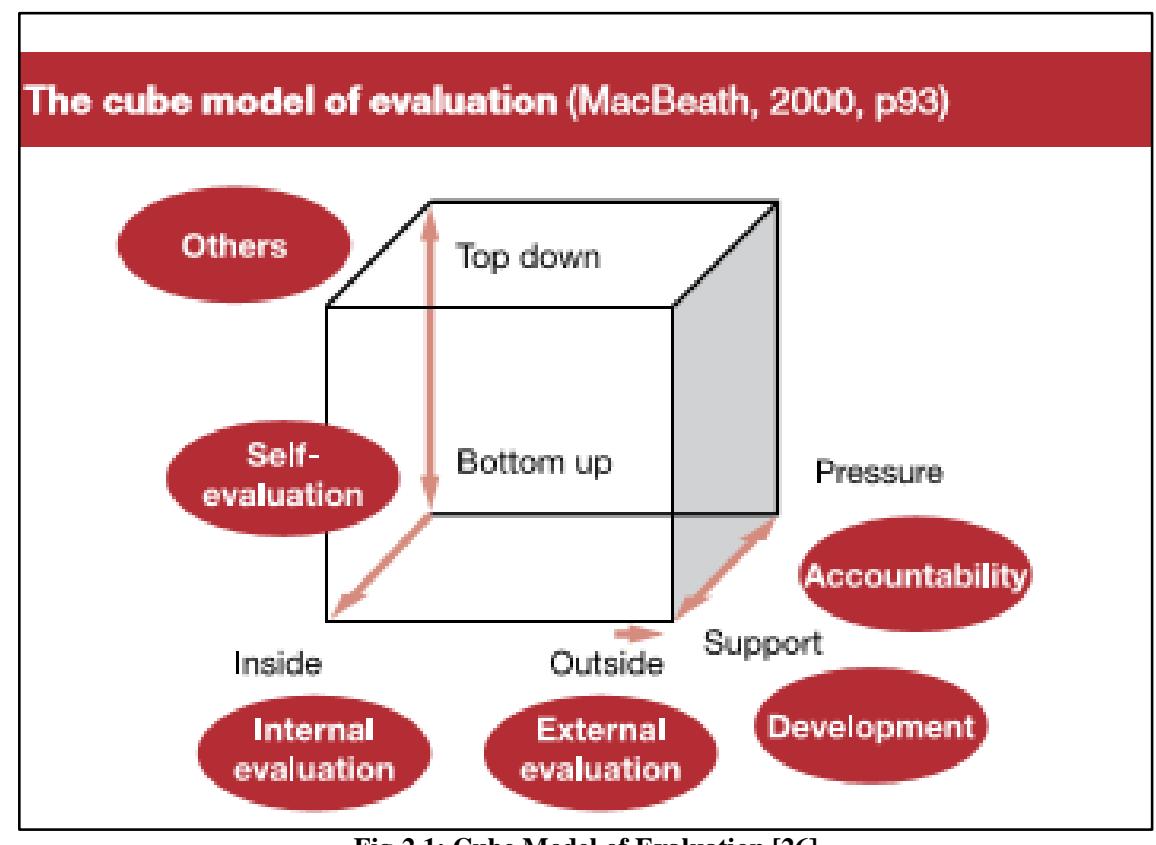

Fig-2.1: Cube Model of Evaluation [26]

\section{Literature Review \\ Challenges Faced by Teachers during Schools' Inspection}

The review of literature reveals that teachers encounter a number of challenges during school inspection and these challenges create in them a negative attitude towards schools' inspection. A study conducted by Perryman [28] in the United Kingdom reveals that throughout his study a negative attitude towards school inspection emerged. The teachers and principals who took part in the study were found to have a negative attitude towards schools inspection as they were forced to pretend to be what they are not just to impress the inspectors thereby meeting the expected standards, and this is one of the challenges that teachers encounter during inspection. In line with this, Brimblecome and Ormston [9] state that as much as inspection is indispensable, it has negative effects on teaching and learning. For these theorists over-emphasis on accountability brings pressure and often creates selfdefensive mechanisms which subsequently hinders selflearning and improvement. Chapman [29] highlights that most teachers get stressed and anxious during inspection as they are not sure whether inspectors would approve or disapprove the way they are teaching because the disapprovals are normally accompanied by shouts and rebukes.
Bowen [4]'s study in England indicated that inspectors tend to be harsh to the teachers and harass them in front of the pupils and this often results to a private cold war between the teachers and inspectors yet they are supposed to have a good rapport. The harassment often makes teachers lose confidence in their professional abilities as the inspectors at times make them feel worthless or inadequate [3].This is in line with OFSTED's [30] view that if inspection is not done in a prudent and professional manner those teachers whose teaching ability was acknowledged as very good are made to feel inadequate by the whole inspection process. Therefore, the act of making teachers feel that they are unable to deliver the content when they are capable of doing it to the best of their knowledge is one of the most frustrating aspects of school inspection.

Machumu [19]'s study reveals that another challenge with school inspection is that school inspectors do not cooperate with teachers when they come for inspection. They do not involve them in the whole process apart from demanding the things that they want, such as the official books. According to the study, inspectors tend to be harsh and they also treat teachers harshly thus flouting the principle of 
friendship. Contrary to this, Alkutich [31]'s study in Dubai on the impact of inspection revealed that school inspection has a significant role in school improvement, especially in teaching and learning.

A study by Ololube [32] in Nigeria, reveals that teachers are scared of inspectors due to the latter's ruthlessness towards the teachers that is portrayed during inspection. The study further unearthed that schools' inspection creates in teachers a negative attitude towards the whole process as they feel that schools' inspection is not helpful in enhancing children's teaching and learning productivity. In a similar manner, Wanzere [33] notes that many teachers are scared of schools' inspectors since the latter show no interest in the whole process after portraying uncooperative attitudes during the exercise. This leaves teachers frustrated.

Similarly, Enaigbe's [34] study found that there are in adequacies of inspection. School inspection, according to this theorist is inadequate and does not meet the needs of schools and parents in that there is lack of collaboration between school inspectors who tend to evaluate teachers based on their own perceptions of teaching and teacher performance without considering official standards. Teacher involvement in the matters of the instruments that are used to evaluate them is not considered. Opportunities for a meaningful dialogue between teachers and inspectors especially after inspections are limited [35, 34, 36]. Sembirige [37] makes the same observation that some school inspectors are ruthless to the teachers and they use bad language when the teachers fail to provide the required documents as this sometimes happens more especially if the documents were not kept properly. For Lyatuu[20] school iinspection has led to poor relations between teachers and inspectors as teachers feel that the inspectors are intruding in their territory, hence school results are affected [20]. In a similar manner Wood's [38] research also indicates that during the inspection exercise most schools/ teachers find the whole process disgusting more especially if the concern by inspectors involves naming and shaming of failing schools. This puts a stigma on the teachers, schools, and headteachers as they do not want to be identified that they come from these failing schools for fear of being labelled as failing teachers [38].

A study by Aguti [39] also suggests that for inspection to achieve its intended purpose, time and frequency need to be considered. The fact that school inspection is not frequently administered in schools is a challenge. For example, Wanzere [33] recommends that school inspection in actual sense is supposed to be carried out regularly due to the fact that many issues manifest in schools daily. Therefore, limited time for considering inspection in schools makes inspection superficial since the inspections are carried out periodically. Wanzere [33] adds that in most cases schools are inspected when there is a negative report about the school that has been received by the Ministry of Education and the knowledge by the teachers that their school is being inspected as a result of that negative report make them view inspection negatively. Aguti [39] states that in addition, most inspections last for a very short time; for example, a few hours in a day, instead of at least a week. This almost renders school inspection to be a police on patrol as there is inadequate time for inspection, which results in the neglect of important areas in school, such as classroom observations, curriculum content, and the general surroundings of the schools [33].

Aguti [39] points out that inspectors should not concentrate on the weak points of teachers without supporting the teachers by ensuring that they do their work effectively. She adds that focusing on the weak points results in tensions which manifest in terms of fear, lack of interest and low morale towards the work, negative attitude of the teachers towards schools' inspection, limited level of professionalism and capability building by their counterparts, schools' inspectors. Aguti [39] stresses that; it can be more helpful if inspectors act as facilitators and supporters in the curriculum implementation role. For Visscher and Coe [40] feedback given after inspection should be made to seem credible and accurate, and perceived as providing information and supporting selfdetermination, rather than surveillance. Visscher et al. [40] posit that feedback should seek to generate feelings of competence but not complacency. In short feedback should be constructive not destructive.

\section{RESEARCH METHODOLOGY}

The qualitative research approach was adopted and used in this study. Creswell [41] and Leedy \& Ormrod [42] posit that in order for a phenomenon to be understood the qualitative approach is ideal because it focuses on gathering information about the phenomenon in a natural setting. The phenomenon in this study was the school inspection process and the challenges that teachers encountered when it was conducted. It is a unique phenomenon because it is not just about anyone who knows it but it is known by people who have experienced it. In order for it to be best understood therefore teachers had to relate their experiences with regards to the challenges that they encounter when the process is carried out. In line with the qualitative research approach, the case study research design was used. Denzin and Lincoln [6] define a case study research as a stand-alone design that can be used in a qualitative research. It has a level of flexibility since it can address a wide range of questions such as why, what, and how of an issue thus assisting the researcher to explore, describe, establish or theorize about complex issues in context.

Data were collected from a purposively selected sample of 14 participants which were selected 
from two less performing schools. According to Sharma [43] purposive sampling, also known as judgmental, selective or subjective sampling reflects a group of sampling techniques that rely on the judgement of the researcher when it comes to selecting the units (e.g. people, case/organisations, events, pieces of data) that are to be studied. In this study the researchers developed an inclusion criterion that was that only teachers who teach English Language in each school from grade 1 to 7 would be chosen from each school. One on one in-depth interviews were employed for the collection of data from the teachers. According to Conein [17] an in-depth interview often involves the asking of questions which the interviewee may never have discussed with anybody or even thought about. The strengths of in-depth interviews according to Seidman [44] are that it allows access to rich personal data, gives the ability to understand an individual's context and motivations, it allows follow up and probing of responses and examination of complexities, it allows the interviewee to talk about what they think is important, also, non-verbal information can be obtained from observing body language and intonation. In this study the researchers were able to get rich detailed information from the teachers on their experiences of schools' inspection through the one on one interviews.

\section{DATA ANALYSIS}

Data analysis is a process of obtaining raw data and converting it into information useful for decision making by researchers. Data are analysed to answer questions, test hypothesis or disapprove theories [45]. Data analysis entails critically analysing the data that have been collected and the responses that have been provided by the participants in the study. Leedy and Ormrod [42] posit that the central task during data analysis is to identify common themes in peoples' descriptions of their experiences, in order to ultimately provide a general description of the phenomenon as seen through the eyes of the people with first- hand experience. Since the study was qualitative, verbatim accounts were presented to support the respondents' experiences on the challenges they encountered during schools' inspection. The recordings were transcribed verbatim from siSwati to English and when they were read certain themes emerged and these were used as sub-topics under which the analysis were based.

\section{Issues of trustworthiness}

The issues of trustworthiness that were adhered to in this study were credibility, transferability, dependability and conformability [46]. Polit and Beck [46] and McMillan and [47] define credibility as the confidence in the truth value of the data and interpretations of them which can be ensured through member checking. In this study member checking was used to validate the obtained data through discussions with the participants. The participants were given the opportunity to react to their responses and to ensure that they did this the analysed data were also referred back to them for review, validation and comments.

Dependability refers to the stability (reliability) of data over time and over conditions [46]. In line with assertion, Gay and Airasian [48] say that this refers to the extent to which the data collection instruments and sources have been chosen carefully. The researchers ensured dependability by doing the study in a way that was procedural such that when the study is repeated with some participants it can produce the same findings. Thick descriptions of the teachers' responses were done during the presentation of data. The data sources were also those that were known could give the required data.

According to Polit and Beck [46] conformability refers to objectivity, that is, the potential for similarities between two or more independent people about the data's accuracy, relevance, or meaning. Agreeing with this idea are Gay and Airasian [48] who state that this ensures that the ideas presented are those of the participants. Conformability was ensured by ensuring that the data would represent the information participants provided and that the interpretations of those data are not imagined by the researcher.

Polit and Beck [46] as well as Gay and Airasian [48] define transferability as the extent to which qualitative findings can be transferred to, or have applicability in other settings or groups, and this was ensured by providing thick descriptions of the research methods applied and the study setting and participants characteristics, as well as verbatim responses given by the participants. It was believed that this could enable anyone interested in making a transfer to reach a conclusion on whether transfer can be contemplated.

\section{Ethical issues}

The researchers attended to research ethics such as informed consent, voluntary participation, and confidentiality as Resnik [8] and Schulze [49] state. The researchers explained the purpose of the study to the participants before they were interviewed and they completed informed consent forms which explained that participation was voluntary and participants could withdraw from the study anytime they felt like and that they were free not to answer some questions if they felt uncomfortable answering them. Participants were also ensured that data were only for academic purposes and would be kept confidentially and anonymity was ensured.

\section{The challenges of school inspection}

In this theme the teachers stated some of the challenges they encountered during school inspection. The analysis of data revealed that the teachers encountered a number of these challenges during schools' inspection. The responses given by the 
teachers revealed that some teachers encountered challenges such as having their lessons disrupted by inspectors, inspectors harassing and disrespecting them in front of learners, and inspectors instilling fear on the English language teachers, as well as inspectors threatening them about losing their jobs.

\section{Inspectors disrupt teaching and learning}

Some of the teachers who participated in the study revealed that the inspectors often showed up at the schools unannounced thereby disrupting the normal school program. According to the teachers' who took part in the study, inspectors come anytime, get into the classrooms and demand official books. The manner in which they come into the classrooms instills fear on the teachers as they demand a lot of things and in the process get the teachers confused and terrified. Responding to this question one of the teachers said:

One challenge is that inspectors disturb the teaching/ learning process because they come unannounced and we have to deviate from our teaching plans as they order us to attend to them and ask us to give them our official books, after which they sit in our classrooms and watch us teach. Due to the manner in which they come and the authority they use when demanding the school books by the time we go back to our teaching we are already disturbed and terrified. It becomes even worse if after having demanded the official books there could be something that will be found to be missing or not in order, as they start shouting there and there (Teacher 1 from school A).

For teacher 1, school A inspectors disrupt the learning process because they come unannounced. For this teacher, this causes a lot of confusion since teachers have to deviate from their planned lesson, as the inspectors order them, to submit their official books. Teacher 1 from school A's experience is in line with the response given by Teacher 4 from school A who pointed out that:

Inspectors disrupt our normal teaching routine because having someone you were not expecting in your class while you teach makes you uncomfortable. It makes you forget to use even the teaching aids you had planned for that lesson, (Teacher 4 from school $A$ ).

A related response was given by another teacher Inspectors disrupt our normal teaching routine because having someone you were not expecting in the class sitting while you teach is challenging sometimes. It makes you to forget (Teacher 4 from school A).
For these teachers inspectors disrupt their normal teaching routine in that having an inspector in the classroom at a time when you were not expecting him/her interrupts the teachers so much that the teacher forgets to use the teaching aids that they had planned to use for their lesson. The teacher tends to focus on this person who has just come in, rather than ensuring that the content $\mathrm{s} / \mathrm{he}$ is delivering is up to the required standard. These teachers' response is in line with teacher 7 from school A who pointed out that Inspectors disrupt our teaching, they just barge into our classrooms, sometimes they tell us our mistakes during the course of the lesson in front of the learners, and this makes us angry, embarrassed, and confused, so much that each time we say something we look at them as we do not know what they are going to say (Teacher 7 from school A).

According to teacher 7 from school A inspectors sometimes disrupt the lesson as they tell teachers their mistakes during the course of the lessons. Both the teacher and the learners are disturbed in the process. For this teacher, being told their mistakes during the course of the lesson disrupts the teaching and learning and it also embarrasses and angers the teachers.

\section{Inspectors harass and disrespect teachers in front of learners}

The teachers that took part in the study revealed that another challenge that they faced during inspection was harassment by the inspectors which led to embarrassment. According to the teachers, inspectors harassed them in front of the learners which made them feel belittled. The inspectors did this if they found certain things that were not in order. Explaining this further one of the teachers pointed out that:

Inspectors harass us in front of the
learners and this embarrasses us
(Teacher 12 from school B).

For teacher 12 from school B, inspectors harass teachers in front of the learners; this teacher said this harassment resulted to their embarrassment. For him, when the inspectors shouted at them whilst they were teaching, they felt harassed, disrespected and embarrassed. Teacher 12 from school B is supported by teacher 4 from school A who said:

Inspectors do not respect us. They focus on negative things instead of helping us improve. Some harass us in front of learners and this ruins our reputation. At the end of each visit we feel harassed, disrespected, belittled and embarrassed. (Teacher 4 from school A) 
This teacher felt inspectors disrespected teachers, by shouting at them during the course of the lesson since the inspectors' main focus are mistakes hence they harass teachers in front of the learners. Teacher 4 from school A went on to say the way teachers are treated by inspectors ruins their reputation. For this teacher being shouted at in front of the learners is disrespect and it leads to embarrassment.

The teachers' responses also revealed that the inspectors were too bossy and instead of guiding the teachers they dictated to them on how they wanted things to be done.

Explaining this another teacher said:

Inspectors are bossy. They harass teachers in front of learners. They do not have any manners. They also demand things that teachers have no power over, for instance teaching aids. Some schools such as this one do not have the money to buy even pieces of chalk let alone charts for teaching aids (Teacher 6 from school A).

For teacher 6 from school A inspectors are bossy. This teacher went on to say that inspectors demanded a lot, do not have manners they just talk anyhow. For him this is harassment.

A related response was also given by another teacher who pointed out that:

Inspectors are harsh; when you make a simple mistake they embarrass you in front of learners. They belittle you, treat you as a kid, not an elder (Teacher 10 from school B).

According to teacher 10 from school B, inspectors are harsh. When teachers do simple mistakes, they embarrass the teachers in front of the learners. The teacher also mentioned that inspectors intimidate them by belittling them. For this teacher, this is disrespect and harassment by the inspectors. Another teacher who made the same observation said:

The challenge is that they always harass teachers. They do not use polite words when talking to them. They always look for mistakes, not for good things or strengths. This makes teachers to feel unappreciated (Teacher 14 from school B).

For teacher 14 from school B, inspectors harass teachers during schools' inspection. This teacher also mentioned that inspectors are not polite towards teachers and this is demotivating. It makes them feel unappreciated.
The teachers' responses indicated that the shouting at by inspectors when they made mistakes was viewed as harassment. It made them feel belittled and embarrassed more especially as it was done in the presence of the learners. Further responses showed that some school inspectors always used stern and harsh language on teachers. These responses also revealed that some inspectors are too bossy as they dictate to teachers always focusing on the teacher's weaknesses and mistakes. This, according to the teachers made them feel unappreciated. These teachers' responses revealed the embarrassment that teachers endured at the hands of inspectors.

\section{Inspectors instill fear on the teachers}

The teachers who participated in the study further revealed that inspectors instilled fear on them and also caused panic. This started when the teachers were told that the inspectors were already in the school or when they were told that they are coming. According to the teachers the mention of inspectors sends chills down their spines. Explaining this one of the teachers said:

Fear is the biggest challenge that we encounter. When we are told that inspectors are around we are engulfed by fear. For me I'm afraid of them because they are harsh to us. (Teacher 3 from school A).

For teacher 3 from school A fear is the biggest challenge for the teachers during the inspectors' visits. Teachers are engulfed by fear when they are told that inspectors are around because they are harsh and they know that they will be shouted at and scolded.

One of the challenges that we face is that schools' inspectors instill fear on us because of the way they talk to us. Like all other human beings we sometimes mess up official books. At times they find that our preparation books are not up to date, and there are no teaching aids together with teaching materials, then they shout (Teacher 5 from school A).

This teacher's response indicated that inspectors instill fear among the teachers. When the inspectors find an official book that is not up to date such as teachers' preparation books, scheme books, register, they take the teachers to task. Sometimes the inspectors fume and get all worked up when they find teachers without teaching aids as well as teaching materials. According to one of the teachers:

Inspectors cause us to be engulfed by fear because as teachers we are always found with faults by the inspectors who are always focusing on mistakes. Sometimes 
we become confused when inspectors come with different ways of doing things, e.g. they give different formats of daily preparation. The other one will say, the other is wrong yet it was said by another inspector (Teacher 7 from school A).

This teacher stated that what instils the fear more in them is that before the inspectors; teachers are always found with faults since the inspectors' main focus is on the mistakes. Another thing that causes confusion is when the inspectors disagree amongst themselves over certain issues, where one inspector would propose that certain things be done in a certain way and another one would oppose that way.

A related response pertaining this issue was Fear is the greatest challenge we encounter as teachers because seeing inspectors makes us to be under a lot of pressure since we are not sure as to what the inspectors will say as they also have the tendency to disagree among themselves on certain issues. Also the criticism is at times unconstructive (Teacher 9 from school B).

For teacher 9 from school B what instils the fear is that teachers get under a lot of pressure since they are not sure as to what the inspectors want and will say. This teacher also highlighted that the criticism given as feedback is at times not constructive.

It was further pointed out that the teachers panic because they know that for whatever mistake they would have made they would be shouted at by the inspectors. This was shown from the response:

\section{Seeing inspector's cause's fear because we know that we may have made mistakes and we are going to be rebuked for those mistakes. For me when I'm told inspectors are around I just panic as I start thinking about whether the official books have been updated or not (Teacher 3 from school A).}

The teachers' responses revealed that the inspectors often instilled fear on them and also cause panic. When the teachers hear that the inspectors are around or coming they start panicking as they always associate their coming with harassment and shouting. Moreover, the officers tend to confuse teachers as they come with different approaches over certain issues and if the teachers try for follow an approach that was given earlier, they find themselves in trouble. The teachers' responses also indicated that inspection puts a lot of pressure on the teachers and they get further disturbed with the harsh and unconstructive criticism. With regards to how these challenges could be minimized, the teachers pointed out that all these challenges could be minimized if inspectors could respect teachers and provide constructive criticism as well as announce the days in which they will visit the schools.

\section{Discussion of Findings}

The findings from the study were that one of the challenges teachers encountered during schools' inspection is that inspectors visit schools unannounced and this disrupts the teaching/learning process. According to the findings of the study inspectors come anytime and demand official books and observe the teachers without any prior notification. This results in the teachers not performing well in their presentation of lessons. They get disturbed so much that they even forget to use the teaching aids. This practice by inspectors is similar to Perryman [28]'s study which revealed that teachers are disrupted during schools' inspection. According to Perryman's study inspection resulted in a three year disruption of teaching practice and this resulted in learners performing poorly.

In addition Sivonike [50] also found that inspection contained more criticism than professional advice. Further, Setlalenoa [51] argued that overemphasis on accountability which comes about as a result of schools' inspection, brings pressure and often creates self-defensive mechanism which subsequently hinders self-learning and improvement. The teachers are totally disturbed as the inspectors come and go as they please, let alone if they demand official books or observe them teaching without notifying them prior about the inspection visit. The normal teaching and learning progress is disrupted as soon as the inspectors arrive with their demands.

This challenge is also in line with Oloube [51]'s observation that inspection develops in teachers a negative attitude towards the inspection process as teachers believe that schools' inspection is not helpful in enhancing children's teaching and learning productivity. Akindele [49] agrees with this assertion as he says a substantial number of teachers are scared of schools' inspectors as they do not know what inspectors are looking for, let alone how long they will be inspecting since impressing the inspectors seems impossible as they are known to be fault seekers who are always on the lookout for mistakes [51].

That teachers are harassed and disrespected by inspectors during schools' inspection also came out in the literature review. A study by Machumu [19] unveiled that inspectors do not cooperate with teachers when they come for inspection. In Machumu's study the inspectors did not involve the teachers in the whole inspection process apart from demanding the things that they wanted such as the official books. Inspectors treated the teachers very harshly and flouted the principle of friendship. The study by Case [52] also indicates that the visits by school inspectors disrupted 
the plans for the teachers as the visits were not announced. Again during inspection the study by Case revealed that inspectors shouted at teachers if they found /noted any form of wrong in their teaching/in the official books. This again is similar to what Bowen [4] notes as he contends that sometimes, inspectors tend to be harsh to the teachers and harass them in front of the pupils and hence pose a challenge in building a rapport between inspectors and teachers which usually extends to a 'private cold war' making it worrisome and often makes teachers lose confidence in their professional abilities. So when inspectors ill-treat the teachers during schools' inspection this leads to a misunderstanding and the inspectors and teachers end up being at loggerheads when they are actually expected to collaborate with each other since they are supposed to work towards a common goal of ensuring learners attain quality education.

Another challenge teachers encountered during inspection was that the inspectors instill fear on the teachers in that they are too bossy and they threaten the teachers with being fired from their jobs due to their inefficiencies when teaching. Further, different inspectors made different and conflicting suggestions on what teachers should do. This then confuses the teachers. Also, harsh criticism disturbs teachers. This study is in line with Sivonike [50] who found out that schools' inspection as a feedback to schools was inadequate as they contained criticism than professional advice. In agreement with this challenge Brimblecome and Ormston [9] state that inspection has negative effects on teaching and learning thus hinders selflearning and improvement.A study that was conducted by Haule [53] revealed that school inspectors treat teachers very rudely and as such teachers perceive schools' inspection as an activity that threatens them and as a result they do not accept the recommendations wholeheartedly. Thus it is important that there is a healthy relationship between teachers and inspectors if inspections are to be efficient and effective.

\section{RECOMMENDATIONS}

Based on the findings from this study the following recommendations were made:

- Teachers should change their negative attitudes towards inspection and be prepared to learn from the inspection process. They should not focus on the negative/unprofessional behaviour that some inspectors exhibit. They should also attend inservice workshops.

- Inspectors should do annual planning and announce dates for their visit. It is also recommended that inspectors should attend in service workshop so to be equipped on how to carry out the inspection process. They should also respect the teachers as professionals and avoid harassing, shouting at them, stopping them in the middle of their presentations if they noted anything wrong. They should also give constructive feedback.

- The study also recommends that there is a need to standardise inspection hence inspectors should follow the inspection guide.

- The study also recommends that The Ministry of Education should come up with policies that protect the teachers from the harsh treatment that they receive from inspectors. The Ministry should also organise workshops for inspectors so that they can be able to carry out the inspection process appropriately.

\section{CONCLUSION}

The study concludes that schools' inspection is a process that is greatly appreciated by teachers as it improves teaching/learning which in turn promotes learners' academic performance. However, the way in which inspectors carry it out develops a negative attitude on the teachers and as such they do not benefit from it. The challenges associated with schools' inspection develop negative attitudes on the teachers.

\section{REFERENCES}

1. UNICEF. (2012). Quality Education. Report of the Advisory Group of Experts for the 2015 Review of the United Nations Peace building Architecture, United Nations, New York.

2. Wilcox. (2013). Inspecting Schools: Holding Schools to Account and Helping Schools to Improve. Buckingham Open University Press.

3. Education and Training Sector Policy of the Kingdom of Eswatini. (2011). Examination Council of Swaziland (ECOS) Newsletter, v2, Issue 3, Jan-April 2017 Mbabane, McMillan.

4. Bowen, G.A. (2010). Teachers' intention to change practice as a result of OFSTED School inspection, Educational Management and management, 24(4), 339-354.

5. De Wolf, I. F. \& Janssens, F.G. (2013). Effects and Side Effects of Inspections and Accountability in Education: An Overview of Empirical Studies. Oxford Review of Education, 33(3), 379-396.

6. Denzin N. K. \& Lincoln Y. S. (2011). The SAGE handbook of qualitative research. 4 th ed. Thousand Oaks, CA: Sage: 2011 b.

7. van het Onderwijs, I. (2011). Alternatieve afstudeertrajecten en de bewaking van het eindniveau in het hoger onderwijs. Utrecht: Inspectie van het Onderwijs.

8. Resnik, D.B. (2011). What is Ethics in Research and why is it important"? http://www.

Niehs.nih.gov/research/resources/bioethics.whatis.c fm.

9. Brimblecome, N. Ormston, M. (2014). 'Teachers' perceptions of School Inspection: A Stressful Experience', Cambridge Journal of Education, 25, 1:53-6

10. Rothman, J. (2018). Social work practice across disability. Routledge. 
11. Department of Education and Skills. (2012). OECD Review on evaluation assessment framework for improving school outcomes: Country background report for Ireland OECD.

12. Ozga, J. (2012). The educational worker? A reassessment of teachers. Schools, Teachers and Teaching (RLE Edu N), 45.

13. Ehren, M.C.M., Altrichter, H., McNamara G. \& O'Hara, J. (2012). Impact of school inspections and learning: Describing assumptions on causal mechanism in six European countries. Educational Assessment, Evaluation and Accountability.

14. Jones, K., \& Tymms, P. (2014). Ofsted's role in promoting school improvement: the mechanisms of the school inspection system in England. Oxford Review of Education, 40(3), 315-330.

15. Close, F. (2014). Too hot to handle: The race for cold fusion (Vol. 1145). Princeton University Press.

16. Rothman, J. (2018). Social work practice across disability. Routledge.

17. Conein, B. (2011). 'Gossip, language and group size: language as a bonding mechanism', Irish Journal of Sociology, 19 (1): 116-31.

18. Rafaeli, S., \& Ludtke, A. G. G. (2018). U.S. Patent Application No. 10/007,799.

19. Machumu, H. (2012). Secondary school teachers' Attitude towards school inspection: A Case Study of Bunda District. Dissertation submitted to Mzumbe University. Unpublished.

20. Lyatuu, J. (2017). Uganda:School Inspections Don't Affect Learning -Researchers. Kampala: The Observer.

21. Ahmed, H. A., Salem, S. A. H., Habashi, A. R., Arafa, A. A., Aggour, M. G. A., Salem, G. H., ... \& Madi, M. (2012). Emergence of Foot-and-Mouth Disease Virus SAT 2 in E gypt during 2012. Transboundary and emerging diseases, 59(6), 476-481.

22. Cronin, M. A. (1997). Systematics, taxonomy, and the Endangered Species Act: the example of the California gnatcatcher. Wildlife Society Bulletin (1973-2006), 25(3), 661-666.

23. De Clercq, F. (2009). School monitoring and change: A critical examination of Whole School Evaluation. Education as change. 11(2): 97-113.

24. Abazov, V. M., Abbott, B., Acharya, B. S., Adams, M., Adams, T., Alexeev, G. D., \& Aoki, M. (2011). Measurement of the anomalous like-sign dimuon charge asymmetry with $9 \mathrm{fb}^{-} 1$ of $\mathrm{p} p$ collisions. Physical Review D, 84(5), 052007.

25. Hamid, Z. Bisschoff, C. and Botha, C. (2015). An analysis of the Swaziland public educational environment and its role-players. Problems and Perspectives in Management, 13(2-1), 129-142.

26. MacBeath, J. (2000). School Inspection and Self Evaluation. New Jersey: Prentice Hall.

27. De Grauwe, A., \& Naidoo, J.P. (2014). School Evaluation for Quality Improvement: an ANTRIE Report
http://unesco.org/Images/0013/001398/139804e.pd f [23 November 2007].

28. Perryman, J. (2010). Improvement after Inspection. Improving Schools, 13(2), 182-196.

29. Chapman, C. (2010). Changing Classrooms Through Inspections. School Leadership and Management, 21(1), 59-73.

30. OFSTED. (2010). The framework for school inspection. London. Unpublished.

31. Alkutich, M. E. (2018). Teachers' perspectives on social media in schools in the UAE.

32. Ololube, N.P. (2014). Teachers job satisfaction and motivation for school effectiveness: An assessment. Helsinki, Finland.

33. Wanzare, Z. O. (2002). Rethinking School Inspection in the Third World: The case of Kenya. Educational Management, Administration \& Leadership, 30(2), 213-229.

34. Enaigbe A. P. (2009). Strategies for Improving Supervisory Skills for Effective Primary Education in Nigeria. Edo Journal of Counselling, 2(2), 235244.

35. Ogunu, M. A. (2001). Problems of school inspection in Nigeria. current issues in educational management in Nigeria. Nigeria association of educational administration and planning.

36. Nkinyangi, S. (2006). Quality Standards and Quality Assurance in Basic Education: Experience from Burundi, Eritrea, Kenya, Rwanda and Uganda. Nairobi Kenya.

37. Sembirige, P. (2009). The role of the district inspectors in improvement of primary schools teaching in selected primary schools in Mukono District.(A case of Mukono and Buikwe Counties).

38. Jefferey, B. \& Woods, P. (2008). Feeling deprofessionalised: The social construction of emotions during an OFSTED inspection. Cambridge Journal of Education, 26 (3), 325-343.

39. Aguti, S. (2015). School inspection and its influence in the quality development of inclusive education practices in Uganda. Oslo University.

40. Visscher, A.J., \& Coe, S.M. (2009). The impact of school inspection and learning British Journal of Educational Studies, 56(2), 205-227.

41. Creswell, J.W. (2014). Research Design: Qualitative, Quantitative and Mixed Method Approaches. Thousand Oaks: Sage.

42. Leedy, P. D., \& Ormrod, J. E. (2013). Practical Research. Planning and Design. New Jersey: Prentice Hall.

43. Sharma. (2017). Pros and cons of different sampling techniques. International Journal of Applied Research: 3(7): 749-752.

44. Seidman, I. (2013). Interviewing as Qualitative Research: A Guide for Researchers in Education and the Social Sciences. New York: Teachers College Press.

45. O'neil, C., \& Schutt, R. (2013). Exploratory Data analysis. Nova Scotia: Fernwood Press. 
46. Polit D.F, Beck C.T, (2014). Essential of nursing research. 8th edition ed. s. 1. : Wolters Kluwer Health/Lippincott Williams and Wilkins.

47. MacMillan, J. H. \& Schumater, S. (2010). Research in Education; Evidence Based Inquiry $7^{\text {th }}$ Edition. Upper Saddle River.

48. Gay, L. R. \& Airisian, P. (2003). Educational Research. Competences for analysis \& Applications. Merril Prentice Hall: New Jersey.

49. Schulze, A. (2012). Ethical Considerations for Internalization: Perspectives from Global Citizenship. Retrieved from http://www.aucc.ca/_pdf/english/publications/inter nationalization_card_e.pdf

50. Sivonike, B. (2015). Rotection of economic rights of authors of traditional songs in tanzania: assessment of the law and pratice (Doctoral dissertation, Mzumbe University).

51. Ololube, N. P., \& Major, N. B. (2014). School inspection and educational supervision: Impact on teachers' productivity and effective teacher education programs in Nigeria. International Journal of Scientific Research in Education, 7(1), 91-104.

52. Myerrs, C.B. (2009). A Case in a case study Methodology. Norway: Sage Production.

53. Haule, M. E. (2012). The perceptions of school teachers and leaders toward school inspections in Tanzania secondary schools: the case of Arusha Municipality (Master's thesis, University of Twente). 